\title{
The work of the deacon according to the Bible and in history
}

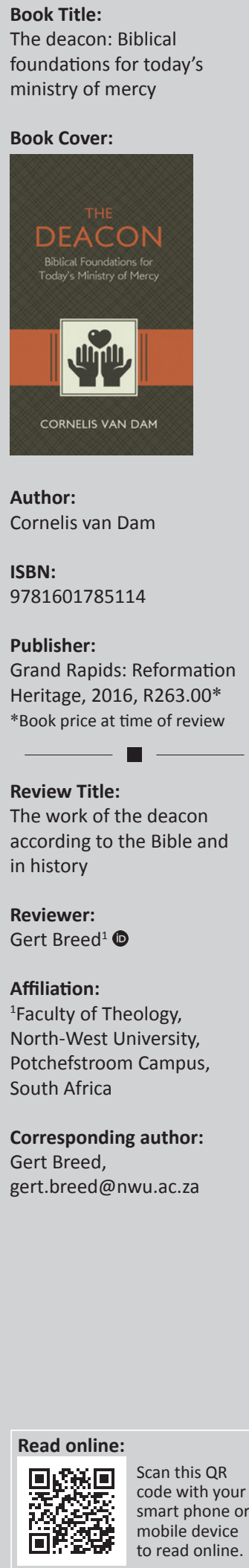

The book is divided into four parts.

In the first part the Old Testament background is described. The goal of this part is stated as follows:

We must attempt to place ourselves in the sandals of those who suffered much so that we have a greater appreciation for those suffering today, as well as for the solutions the Lord prescribed.

With this goal setting van Dam connects the work of the deacon with the care of the poor without motivation for this restriction on the work of the deacon.

The first chapter describes the various categories of poor, named according to words used in the Old Testament. The following manifestations of poverty are then discussed: The peasant farmer and the landless poor; the widows and the orphans; the sojourners; the foreigner and the Levite. The first chapter is closed with a look at God's laws about caring for the poor, whereby Israel should have been a light to the nations.

The second chapter looks at the way Israel should have provided for the poor. Different questions such as why Israel needed to help the poor; how the eight commandment relates to helping the poor; and how the poor should be helped in the family, the society and by the state are answered. The chapter closes with a look at the possibility of an Old Testament deacon. The conclusion is that there are no direct lines from the Old Testament to the New Testament deacon.

The second part of the book looks at New Testament times in four chapters. Chapter 3 discusses Christ's teaching on the poor and the needy. The historical context of his teaching is described: Christ's teaching in deeds and words receives attention, describing his life of service and his teaching about service to the poor and the necessity of each Christian to love their neighbours.

In chapter 4, Acts 6 is discussed. A thorough description of the situation of the widows of the Greek speaking Jews are given and the identity of the seven men, chosen to attend to the problem, is discussed. Without thorough motivation, the seven is described as deacons. Van Dam acknowledges the academic discussion about the identity of the seven as deacons, but he deemed it not necessary to take the reader into the discussion. On page 55 he acknowledges that the activities of the seven men give reason for doubt that these seven were deacons, because Philip and Stephen also preached. With this, he is reading a current view (a deacon does not preach) on the work of the deacons back into the Bible and his previous unmotivated assumption that the seven were deacons can come under severe scrutiny.

Chapter 5 gives an in-depth discussion of the requirements for the office of deacon which is a good contribution to the discussion around this office. The chapter ends with the comparison of the ministry (diakonia) of the apostles and the seven men of Acts 6. In the discussion, there is no clear distinction between the apostles of Acts 6 and the elders of today. The question is whether it is a legitimate exegesis to say that the elders' work is the same as that of the apostles of Acts 6, or whether the task of the seven was a service which eventually led to the institution of the service of both elders and deacons. Van Dam does not address these questions satisfactorily or convincingly. The statement on page 74 illustrates the problem with the exegetical method: 'The seven in Acts were specifically appointed to do diaconal work.' Before Acts 6, there is no description of what diaconal work entails. The writer is reading his perspective on diaconal work back into the work of the seven. Even if the seven's work were caring for the poor, was that the

How to cite this book review: Breed, G., 2018, 'The work of the deacon according to the Bible and in history', In die Skriflig 52(1), a2385. https://doi.org/10.4102/ids.v52i1.2385

Copyright: ( 2018 . The Authors. Licensee: AOSIS. This work is licensed under the Creative Commons Attribution License. 
work of the diakonoi of Philippians 1 or 1 Timothy 3? There is no basis for this assumption. Chapter 6 is a thorough discussion of the possibility of the female deacon from different Scripture parts.

The third part of the book looks at the office of deacon in the history of the church. Chapters 7 and 8 give a useful description of the history of the diaconal work in the Early Church and the Reformation, and the place of women in this work.

Part 4 describes the current functioning of the office of deacon, consisting of four chapters. Chapter 9 describes the ecclesiastical position of the deacon. Chapter 10 looks at the equipping of deacons, chapter 11 describes some practical tasks of the deacon in the congregation and some key principles underlying the service of the deacon. Chapter 12 describes the work of the deacon outside the congregation. Chapter 13 summarises the task of the deacons towards the poor.

At the end of the book, questions for study and reflection, selected resources, specialised resources as well as a Scripture and subject index are given.

Summary: There are a lot of useful information in the book of Cornelius van Dam and it can be useful for deacons and pastors in equipping deacons. The one big deficiency is the assumptions about diaconal work that he comes upon in the study of Acts 6 without reflecting on the latest research (for example that of John N. Collins and Anni Hentschel), or by answering in-depth to other interpretations of this text. 